\title{
Komparatív elónyök, ökológiai ártalmak, társadalmi károk a világállam és a nemzetállamok világának fényében
}

\section{Comparative Advantages, Ecological Dangers, Social Harms in the Light of the World State and Nation States}

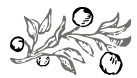

\section{Összefoglalás}

A nemzetközi gazdaságtan uralkodó szemlélete jól bemutatható Paul Krugman és Maurice Obstfeld komparatív előnyök modelljén. A modell érték- és célrendszere, a világpiaci árarányváltozások, a technológiai haladás hatása, a volumengazdaságosság, a munkamegosztás társadalmi következményei és a negatív externáliák veszélyei kerülnek előtérbe. A szerzôpáros csak azokkal a megfontolásokkal számol, amelyek a volumengazdaságosság révén akár növekvố hozadékot is eredményezhetnek a termelók számára, s innen egyenes út vezet az „egy cég termeljen bizonyos jószágokat a világ öszszes fizetôképes fogyasztójának” világállami elképzeléshez. Kritikánk során igyekszünk rámutatni a modell korlátaira, esetenként korlátoltságaira. A krugmani-obstfeldi modell világállam apologetikájával szemben arra hívjuk fel a figyelmet, hogy a filozófiai antropológiailag, ontológiailag, axiológiailag, etikailag és ökológiailag megalapozott világgazdaság csak a nemzetgazdaságok és a régiók harmonikus, visszafogott múködése mellett felelhet meg a 21. századi kihívásoknak.

Dr. Somogyi Ferenc, egyetemi docens, Széchenyi István Egyetem Nemzetközi és Elméleti Gazdaságtan Tanszék (somogyif@sze.hu). 
Journal of Economic Literature (JEL) kódok: D2, F12, N10, O3, P5

Kulcsszavak: Krugman-Obstfeld-modell, utilitarizmus, technológiai változás, volumengazdaságosság, negatív externáliák, világállam, nemzetállamok világa

\section{Summary}

The leading perception of international economy can be fully described through the works of P. Krugman and M. Obstfeld's model of comparative advantages. The paper tackles the values and aims of the model, the world market price changes, the effects of the technological advancement, the economies of scale, the social consequences of the division of labour, and the risks of negative externalities. The authors only consider conditions suitable for achieving increasing yield for producers on account of the economies of scale, and this directly leads to the concept that "a single company should produce one type of a product for all the solvent consumers of the world". In our criticism, we endeavour to point out the limitations and misconceptions in the model. In contrast to the apologetics of the Krugman-Obstfeld world-state model, we point out that a philosophically anthropologically, ontologically, axiologically, ethically and ecologically functional and grounded world economy can only meet the 21st-century challenges if well-regulated nation-states operate harmonically.

Journal of Economic Literature (JEL) codes: D2, F12, N10, O3, P5

Keywords: Krugman-Obsfeld model, utilitarianism, technological change, economies of scale, negative externalities, world state, nation states

„Azokkal szimpatizálok, akik minimalizálnák, s nem azokkal, akik maximalizálnák a nemzetek közötti gazdasági összefonódásokat. Eszmék, tudás, múvészet, vendégszeretet, utazás - ezek azok a dolgok, amelyeknek természetük szerint nemzetközieknek kell lenniük. (De a javakat hazai keretek között kell elóállítani, amikor az úgy természetes és észszerú.) Azonban - ha az észszerüen és praktikusan lehetséges - az árukereskedelem ne lépje át az országhatárokat, és mindenekelôtt a pénzügyek is legyenek nemzetiek."1

John Maynard Keynes

\section{BEVEZETÉS}

Az uralkodó szemléletú közgazdaságtan a nemzetközi gazdasági folyamatok megkérdőjelezhetetlen motorjának a komparatív előnyök kihasználásának ösztönzô erejét tartja. A felsőfokú képzés tananyagai, a kézikönyvek s az ezekre épülô külgazdaságtani, világgazdaságtani szakirodalom egységességérôl könnyedén meggyôzôdhetünk, ha a legfontosabb hazai és nemzetközi múveket nyomon követjük. A második világháború után a posztkeynesiánusok fogalmaztak csak meg odafigyelésre érdemes, tényekkel alátámasztott ellenvetéseket. ${ }^{2}$ A neoliberális egyeduralom térhódításától a mai napig ezek az ellenvetések elveszítették - a valóság egyre nyilvánvalóbb tényei ellenére - 
pozíciójukat. Megemlíthetjük még az ún. alternatív, illetve ökológiai ökonómiai múvek fenntartásait is, de ebben az esetben már az „alternatív” és az „ökológiai” jelzô elegendő ok, hogy az uralkodó közgazdaságtan „tudomást se vegyen” a komparatív előnyök kritikájáról. Ilyen elmélettörténeti háttér mellett teszünk arra kísérletet, hogy rávilágítsunk (a pozitivista beállítottságú közelítés itt úgy fogalmazna, hogy „bizonyítsuk"): a komparatív elônyök dogmája tarthatatlan jelenlegi abszolutizált szerepében; a gazdasági, a társadalmi és az ökológiai fenntartásaink ezt támasztják alá.

1870-ben a világ bruttó hazai termékének 4,6\%-a volt export, illetve import, napjainkban (2018) ez a szám kb. valamivel 20\% felett van. Amellett szeretnénk érvelni, hogy a nyugati civilizáció ökológiai és humánökológiai önmegsemmisító folyamataihoz (pl. klímaváltozás, biodiverzitás-vesztés, az embert „felparcellázó” munkamegosztás, irracionális migráció) jelentôs részben a nemzetközi kereskedelem járul hozzá, a nemzetközi kereskedelem elemének tekintve az infokommunikációs szolgáltatásokat is. Úgy is fogalmazhatunk, hogy a leglátványosabb gyakorlati, felszíni jelenségról van szó. A nyugati civilizáció összeomlása vagy „Nagy Reccs”-ekbe torkollása akár ezen a ponton is felszínre törhet. A litoszféra, a hidroszféra, az atmoszféra, a bioszféra végzetes károsítása jelentôs részben a világkereskedelmet bonyolító közlekedési hálózathoz kötődik. A repülőgépek, a hajók, a vonatok, a kamionok okozta ártalmakra ugyan utalunk, de nem ezekre az evidenciális szintú tényekre koncentrálunk. Inkább arra összpontosítunk, hogy az uralkodó nemzetközi gazdaságtan alapmodelljeiben kimutassuk azt a hiányt, durvábban fogalmazva, vakságot, még durvábban fogalmazva, tudatos tendenciózus torzítást, amelyet a komparatív elônyök dogmájával lepleznek az uralkodó közgazdaságtant vezetô paradigmaszerepben tartó érdekkörök, libertinus globalokrata tudósok, politikusok, médiamogulok, az óriás transz- és multinacionális cégek csúcsmenedzserei. Kritikánk nem fog minden részletre kiterjedni, de nincs is erre szükség. A gyakorlati döntések elvárt elégséges szintjét jóval túllépjük, ha a nemzetközi kereskedelem apologetikus modelljeinek legfontosabb prekoncepcióit elôtérbe állítjuk, s megadjuk kritikájukat. Foglalkozunk a modellek érték- és célrendszerével; a világgazdaság szerkezeti átrendezôdésének hatásával; a technológiai változás szerepével; a volumengazdaságosság előtérbe kerülésével; a munkamegosztás társadalmi következményeivel; s végül a negatív externáliák létfeltételeket veszélyeztetô kritikus felhalmozódásával. ${ }^{3}$

\section{Az URALKODÓ KÖZGAZDASÁGTAN ABSZOLUTIZÁlT ÉRTÉK- ÉS GÉLRENDSZERE}

Paul R. Krugman ${ }^{4}$ és Maurice Obstfeld 872 oldalas egyetemi tankönyvükben azzal az igénnyel léptek fel, hogy egyesítik a nemzetközi kereskedelem három legismertebb modelljét; kiküszöbölik a hiányosságaikat, s megtartják az erényeiket (Krugman-Obstfeld, 2003). ${ }^{5}$ David Ricardo eltérô relatív termelékenységen alapuló komparatív elôny tanában, Paul Samuelson és Ronald Jones specifikus tényezók modelljében, Eli Heckscher és Bertil Ohlin tényezőarányok elméletében közös és a Krugman-Obstfeld-alapmodellben is megkérdőjelezhetetlen a világtermelés és -fogyasztás növelésének értéke 
és célja. ${ }^{6}$ Az alapmodell feltételei konvencionálisan: két országra, két termékre, két erőforrásra redukált a világgazdaság, a tökéletes világpiac relatív termékárai adottak, adott továbbá a kiemelt nemzetgazdaság nemzetikibocsátás-értéke, itt az ún. isoértékvonal ${ }^{7}$ elnevezést kapta. A gazdaság a folytonos termelési lehetôség határa ${ }^{8}$ és az isoértékvonal érintôjében teremt maximális kibocsátást. Ez a kibocsátási érték (termelés) megegyezik a fogyasztással. Ex ante világkereskedelem állapotában vagyunk. Szimbólumokkal: $\mathrm{V}=\mathrm{P}_{\mathrm{C}} \cdot \mathrm{Q}_{\mathrm{C}}+\mathrm{P}_{\mathrm{F}} \cdot \mathrm{Q}_{\mathrm{F}}=\mathrm{P}_{\mathrm{C}} \cdot \mathrm{D}_{\mathrm{C}}+\mathrm{P}_{\mathrm{F}} \cdot \mathrm{D}_{\mathrm{F}}$ ahol: $\mathrm{V}=$ isoértékvonal, $\mathrm{P}_{\mathrm{C}}=\mathrm{a}$ ruházati cikkek ára, $P_{F}=$ az élelmiszerek ára, $Q_{C}=$ a ruhatermelés mennyisége, $Q_{F}=a z$ élelmiszer-termelés mennyisége, $\mathrm{D}_{\mathrm{C}}=$ a ruházati cikkek keresletének a mennyisége, $\mathrm{D}_{\mathrm{F}}$ $=$ az élelmiszerek keresletének mennyisége. $\mathrm{A}_{\mathrm{C}} \cdot \mathrm{Q}_{\mathrm{C}}+\mathrm{P}_{\mathrm{F}} \cdot \mathrm{Q}_{\mathrm{F}}$ tehát a termelés, a $\mathrm{P}_{\mathrm{C}} \cdot \mathrm{D}_{\mathrm{C}}$ $+\mathrm{P}_{\mathrm{F}} \cdot \mathrm{D}_{\mathrm{F}}$ a fogyasztás. $\mathrm{S}$ most induljon meg a külkereskedelem! A szuverén fogyasztó ízlésétôl függ, ${ }^{9}$ hogy az isoértékvonal (V) mely pontja a valóság, s ez természetesen nem csak az érintési pont lehet. A külkereskedelem tehát biztosítja, hogy a termelési lehetôség határán túl is fogyaszthasson a fogyasztó. Választását az isoértékvonalat érintô közömbösségi görbe határozza meg. ${ }^{10}$ Természetesen ezzel a közelítéssel „magunkra húzzuk" az ezer sebből vérzó szubjektív határhaszon-elméletet, a tarthatatlan, utilitarizmuson alapuló értékvilágot ${ }^{11}$ és a primitív közgazdaságtani emberkoncepciót, a „homo oeconomicus"-t. ${ }^{12}$ Lásd az 1 . ábra $\mathrm{D}_{1}$ pontját, amely kívül van a termelési lehetôség határán. $V_{1}$ isoértékvonalon a hazai termelést $\left(Q_{1}\right)$ a $Q_{C 1}$ ruházati cikk mennyisége és $Q_{\mathrm{F} 1}$ élelmiszer-termelés határozza meg. $\mathrm{V}_{1}$ mellett a fogyasztás: $\mathrm{D}_{1}\left(\mathrm{D}_{\mathrm{Cl}}, \mathrm{D}_{\mathrm{F} 1}\right)$. Ez úgy lehetséges, hogy $\mathrm{Q}_{\mathrm{C} 1}-\mathrm{D}_{\mathrm{Cl}}$ ruhamennyiséget exportálnak, és $\mathrm{D}_{\mathrm{F} 1}-\mathrm{Q}_{\mathrm{F} 1}$ élelmiszer-menynyiséget importálnak. Mivel a $Q_{1}$ és a $D_{1}$ az isoértékvonalon helyezkedik el, így nem kell számolni a külkereskedelmi mérleg egyensúlyának felborulásával; az exportból fedezett az import.

Máris levonhatjuk az elsó fontos következtetést: a külkereskedelem révén a külkereskedelem elôtti állapothoz képest adott relatív árak mellett $\left(\mathrm{P}_{\mathrm{C}} / \mathrm{P}_{\mathrm{F}}\right)_{1}$ ugyanolyan értékben kevesebb ruhát $\left(Q_{\mathrm{Cl}}-\mathrm{D}_{\mathrm{Cl}}\right)$ és több élelmiszert fogyasztanak $\left(Q_{\mathrm{F} 1}-\mathrm{D}_{\mathrm{F} 1}\right)$. A külkereskedelem elôtt hazai viszonyok közepette $Q_{\mathrm{C} 1}$ ruhát és $Q_{\mathrm{F} 1}$ élelmiszert fogyasztottak. A fogyasztási szerkezetben bekövetkezett változás (értékváltozás nincs) arról árulkodik, hogy az új naturális kombináció $\left(\mathrm{D}_{\mathrm{Cl}}, \mathrm{D}_{\mathrm{F} 1}\right)$ a termelési lehetôség határán kívül van. Termelôk felóli változás nem történt, ugyanannyi ruhát és élelmiszert termelnek, mint a világkereskedelem előtt. A fogyasztói preferenciarendszer változása (kevesebb ruha, több élelmiszer) igényéhez a termelô, illetve a kereskedô tehát úgy tud alkalmazkodni, ha exportál (ruha), illetve megjelenik az import (élelmiszer). A termelési lehetôség határán kívül lévô lehetetlen kombinációk a külkereskedelemmel lehetôvé váltak. A fogyasztási szerkezetben bekövetkezett változás, az ún. helyettesítési hatás (több élelmiszer, kevesebb ruha) jól példázza a régióhoz nem kötôdô fogyasztó szabad választását. A pénzérték változatlansága mellett, pusztán a nemzeti határokon átnyúló szabadkereskedelem biztosította, hogy a fogyasztó a hazai lehetôségein túl válassza meg fogyasztói kosarának összetételét. $Q_{1}$ pontban a hazai termelés maximalizálásának célja, a $D_{1}$ pontban a fogyasztók maximális választási szabadsága megvalósult. E célok, tágabban értelmezve értékek kritikáját a következó fejezetekben adjuk meg. 
Somogyi Ferenc: Komparatív elönyök, ökológiai ártalmak, társadalmi károk...

\section{A VILÁGPIAC VÁlTOZÁSAINAK HATÁSA: VILÁGPIACI ÁRARÁNY VÁLTOZÁSA}

A továbbiakban számoljunk a világpiac - bármilyen forrásból fakadó - változásaival. Ezeknek az átrendezódéseknek a megjelenési formája, hogy megváltoznak a világpiaci árarányok. Növekedjen a ruházati cikkek relatív világpiaci ára: $\left(\mathrm{P}_{\mathrm{C}} / \mathrm{P}_{\mathrm{F}}\right)^{1}<\left(\mathrm{P}_{\mathrm{C}} / \mathrm{P}_{\mathrm{F}}\right)^{2}$. Ekkor az isoértékvonal meredeksége nô $\left(\mathrm{V}_{2}\right)$. A cserearány-változás mögött az érintett termelốk versenyképesség-sorrendjének az átrendeződése áll. A komparatív előny érvényesítésének motívuma realizálásra törekszik, az érintett szereplók alkalmazkodnak a változásokhoz. Az új termelési kombináció: $\mathrm{Q}_{\mathrm{C} 2}, \mathrm{Q}_{\mathrm{F} 2}$, a fogyasztási kombináció: $\mathrm{D}_{\mathrm{C} 2}$, $\mathrm{D}_{\mathrm{F} 2}$. A ruhatermelés nô $\left(\mathrm{Q}_{\mathrm{C} 2}-Q_{\mathrm{C} 1}\right)$, az élelmiszer-termelés csökken $\left(\mathrm{Q}_{\mathrm{F} 1}-\mathrm{Q}_{\mathrm{F} 2}\right)$. A ruhaexport: $\mathrm{Q}_{\mathrm{C} 2}-\mathrm{D}_{\mathrm{C} 2}$, az összes élelmiszerimport: $\mathrm{D}_{\mathrm{F} 2}-\mathrm{Q}_{\mathrm{F} 2}$. A fogyasztás a termelési lehetôség határától még távolabb került: $\mathrm{D}_{1} \rightarrow \mathrm{D}_{2}$. $\mathrm{A}_{1}$ fogyasztási kombinációhoz képest $\left(\mathrm{D}_{\mathrm{C} 1}, \mathrm{D}_{\mathrm{F} 1}\right)$ az új $\left(\mathrm{D}_{2}\right)$ kombináció $\left(\mathrm{D}_{\mathrm{C} 2}, \mathrm{D}_{\mathrm{F} 2}\right)$ mindkét termék esetén nagyobb. A hazai ruházaticikk-fogyasztás $\Delta \mathrm{D}_{\mathrm{C}}$-vel $\left(\mathrm{D}_{\mathrm{C} 2}-\mathrm{D}_{\mathrm{C} 1}\right)$, az élelmiszer-fogyasztás $\Delta \mathrm{D}_{\mathrm{F}}$-fel $\left(\mathrm{D}_{\mathrm{F} 2}-\mathrm{D}_{\mathrm{F} 1}\right)$ nôtt. A külkereskedelem újabb diadalt ülhet, ezúttal nem az ízlésváltozás okozta szerkezeti változás révén került a fogyasztás a termelési lehetôség határán kívülre, hanem - nem megfeledkezve a továbbra is fennálló fogyasztói szabad választás lehetôségérôl - a kompetitivitás, illetve a komparatív elóny vezetett új árarány mellett nagyobb ruha- és élelmiszer-fogyasztáshoz. Itt homályban maradnak a transzferköltségek és a negatív externáliák. Pedig a növekvô ruhaexport $\left(\mathrm{Q}_{\mathrm{C} 2}-\mathrm{D}_{\mathrm{C} 2}\right)$ és az óriási élelmiszerimport $\left(\mathrm{D}_{\mathrm{F} 2}-\mathrm{Q}_{\mathrm{F} 2}\right)$ talán okot kellene hogy adjon a többlettranszferköltségek elemzésére és a növekvố negatív externáliák megjelenésére.

Levonhatjuk a második következtetésünket: változatlan termelési lehetóség határgörbéje mellett a világpiaci relatív árarányváltozások (hazai nézôpontból a cserearány nôtt) jelentôs élelmiszer- és ruházaticikk-fogyasztást implikálnak. Ha a fogyasztás nô, akkor az uralkodó közgazdaságtan igazolva látja a gazdaság szerkezetében bekövetkezett változást, pontosabban a világpiaci változások komparatív elônyök érvényesítése révén kiaknázott lehetôségét. Az anyagi gazdagság adott erôforrások mellett a már korábban elért maximumon áll, a fogyasztás viszont az elôzó állapothoz képest növekedett, mindkét jószág vonatkozásában.

Ezen a ponton nem mehetünk el a közgazdaságtan elmélettörténetének azon amnéziája mellett, amelynek hiányában látványosan és folyamatosan igazolható lehetett volna, hogy a 19. században útjára induló liberális kapitalizmus ${ }^{13}$ civilizációs zsákutca, amelynek utolsó etapja - megfelelve a kétszáz éves szellemi áramlatok ciklusidejének a 21. század elsố évtizedeiben éri el mély-, illetve fordulópontját. A 19. század elsố harmadában berobbanó exponenciális termelés- és népességnövekedés képtelenségével a kor legjelesebb szerzói tökéletesen tisztában voltak. John S. Mill figyelmeztetése így szólt: „A tốke és a népesség változatlan állapota nem jelenti az emberi fejlődés változatlan állapotát. A szellemi kultúra minden fajtájának, valamint az erkölcsi és a társadalmi haladásnak itt legalább akkora tere lenne, mint bármikor is volt. Ugyananynyi lehetôség nyílna az élet múvészetének fejlesztésére, és sokkal több valószínúsége lenne annak, hogy az valóban fejlődjék is” (Mill, 1900:264). Malthus is a „társadalom 


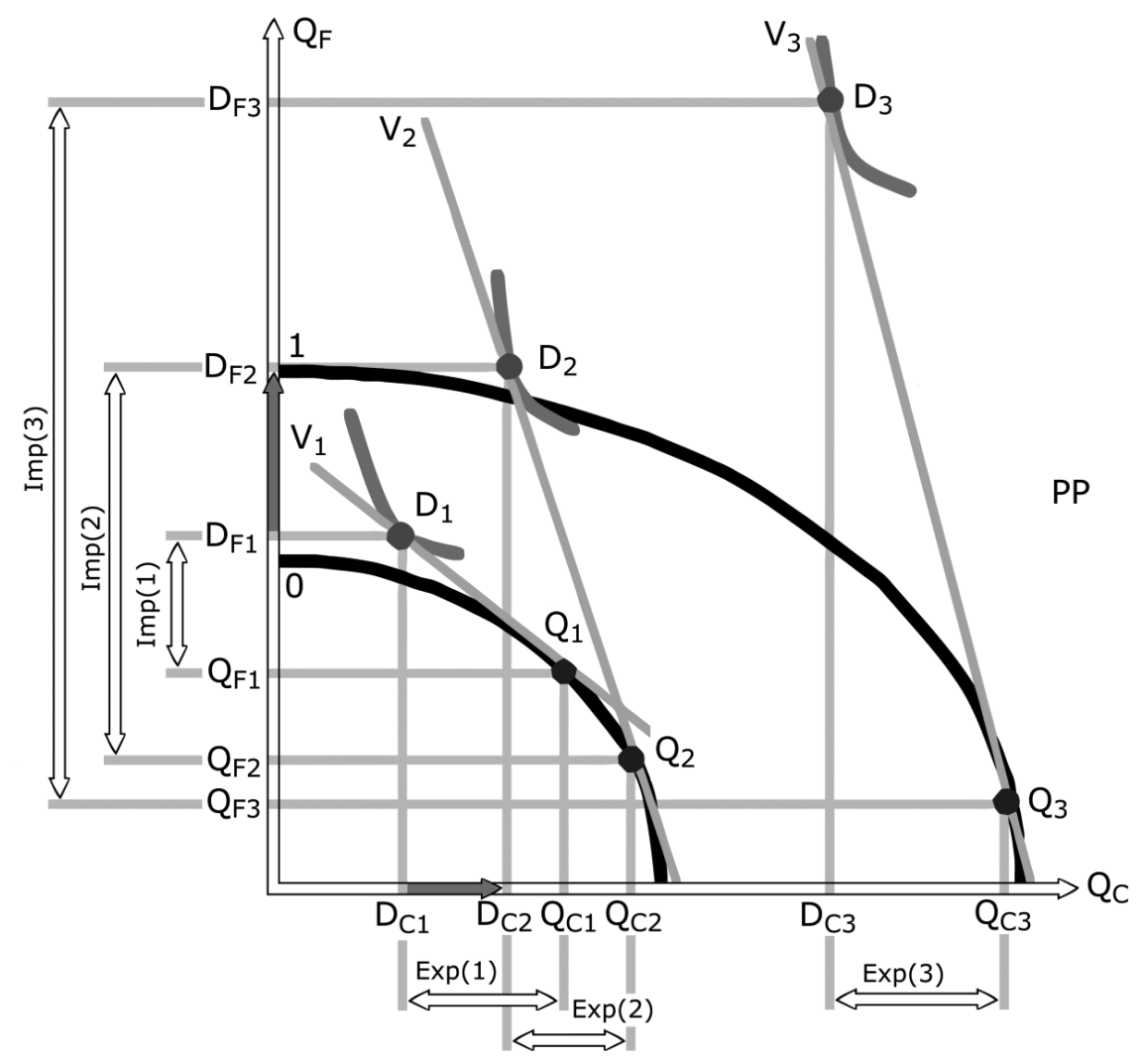

Forrás: P. Krugman - M. Obstfeld alapján továbbfejlesztett saját szerkesztés

javítása” céljából hívta fel a figyelmet, hogy „minden élónek az az állandó hajlandósága, hogy a rendelkezésre álló táplálékmennyiségen túl szaporodjék”. ${ }^{14} \mathrm{~A}$ klaszszikus közgazdászok figyelmeztetését úgy foglalhatjuk össze, hogy pontosan látták a végesnek (Föld) feszülő expanzív népesség- és termelésnövekedés képtelenségét - és ezzel a képtelenséggel él együtt az emberiség idestova kétszáz éve. Sôt, továbbmehetünk, a liberális kapitalizmus egy egész gazdaságszervezôdést és mögé állított apologetikus társadalom- és szellemtudományi apparátust épített ki e folyamatok mögé, amikor alapértékké és alapcéllá tette a termelés és a fogyasztás maximalizálását. Jeremy Bentham utilitarizmusa közel kétszáz éve hódít, illetve valamivel több, mint száz éve (a szubjektív határhaszon-elmélet uralkodóvá válásával) a nyugati közgazdaságtani tananyagok „princípiuma”. ${ }^{15}$ 
Somogyi Ferenc: Komparatív elönyök, ökológiai ártalmak, társadalmi károk...

\section{A TECHNOLÓgIAI VÁltozÁS SZEREPE}

Vonjuk be modellünkbe a technológiai változás jelenségét! ${ }^{16}$ Amikor az 1. ábra termelésilehetôség-határán mozgunk $\left(Q_{1} \rightarrow Q_{2}\right)$, akkor a termelésszerkezeti módosulás mögött a technológiai változás is áll, aggregált hatékonyságváltozás viszont nem. Ha a termelési lehetôség határának meredeksége vagy/és helyzete megváltozik, akkor a technológiai változás hatékonyságcsökkenést vagy -növekedést vált ki. A technológiai változás hatását ekkor a gazdaságon belül értékeljük csupán, tehát nem számolunk a természeti és társadalmi következményekkel.

Ha az egyes jószágok termelésének hatékonyságnövekedése különbözố mértékú, akkor „kibillentô” hatású növekedésrôl van szó. Induljunk ki abból, hogy a ruhatermelés hatékonysága jobban nôtt, mint az élelmiszer-termelés hatékonysága. Ekkor az 1. ábrán a termelési lehetôség bázisgörbéje (0) a termelésilehetôség-görbe új állapotába (1) kerül; az abszcisszát metszố termelési lehetôség határa jobban jobbra nyúlik kifelé, mint az ordinátát metszố termelési lehetôség szakasza. Minden ilyen kitolódás a termelés színvonalát emeli, s természetesen még nagyobb fogyasztást is jelez. Egyébként a termelési lehetôség határa az erôforrások bôvülésének hatására szintén jobbra „kifelé” tolódik.

Harmadik következtetésünk: a technológiai változás vagy erôforrás-növekedés (eddig ezt is adottnak vettük) úgyszintén a naturális fogyasztás növekedéséhez vezet. (Ezúttal, a zsúfoltság elkerülése érdekében nem tüntetjük fel az isoértékvonal további jobbra forgását, s nem jelezzük az új közömbösségi görbe új érintési pontját, amely ismételten nagyobb fogyasztást tesz lehetôvé mindkét termékbôl.) Itt hívjuk fel a figyelmet arra a vakságra, arra a legelemibb kommunikációs hiányra, amely a közgazdász-társadalom, pontosabban a technokrácia és a nyugati világ legjelesebb civilizációkritikusai között jött létre. A civilizációkritikusok világnézeti alapállásuktól függetlenül egy platformra kerültek, mint ahogy a technokrácia és a technokrácia által orientált fogyasztói tömegek is. A civilizációkritikusok az ókortól napjainkig nem gyôzik hangsúlyozni a - mai fogalmainkat használva - technológiai változás parttalan felszabadításának veszélyeit. Hozzájuk csatlakoznak számos esetben - többnyire alkotókorszakuk végén - azok a zseniális természettudósok (pl. Neumann János, Albert Einstein stb., a sor hosszan folytatható), akik a technológiai change kontrollálatlan burjánzásának az emberi létezés szempontjából végzetes következményeire hívják fel a figyelmet. A nyugati kultúra talán elsô „közgazdasági” múvében Hésziodosz Zeusz szájába adja Prométheusz kritikáját: „Iapetosz fia, minden másnál hát ravaszabb vagy, / annak örülsz, hogy megcsaltál s elloptad a lángot, / mely bajt hoz tereád s a jövóben az emberi nemre. / Túz kellett? Adok én majd nékik olyan veszedelmet, / hogy szeretik s körülujjongják a saját veszedelmük"17 (Hésziodosz, 1974:42.). Erre a haláltáncra hívja fel a figyelmet a 20. század egyik legnagyobb gondolkodója, Martin Heidegger is. A nemkívánatos következményekkel járó nagytechnikák („csinálmányok”) olyan pályákon mozognak, amelyek „a világ elsötétüléséhez és a föld pusztulásához” vezetnek. Az elsố pálya a csinálmányok matematikai kiaknázásának végtelen lehetôségében gyökerezik. A második pálya az ember fizikai alkalmazkodóképességét semmibe vevố 
sebesség támogatását jelenti (pl. informatikai eszközök, közlekedés, biotechnika). A harmadik pálya úgyszintén felfüggeszti az ember elemi antropológiai adottságait, amikor grandiózus csinálmányokat hoz létre (pl. atomerômúvek, gátrendszerek, kemikáliák). S végül, a negyedik pálya a számban és a kiszámíthatóságban gyökerezô tömegszerúséget juttatja uralomra. E pályák elôrehaladása a modern tudomány és a technika természet, társadalom és az emberi psziché feletti uralmát ígéri, s ezzel együtt „ma még elképzelhetetlen állapotokig [fokozza] a föld kizsákmányolását és kihasználását, valamint az ember tenyésztését és idomítását”. ${ }^{18}$

A „számításon”, tehát nem minôségen, az emberléptéket meghaladó „sebességen”, „grandiozitáson”, „tömegszerúségen” alapuló nagytechnikai rendszerek az újkori kontrollálatlan tudomány bázisán a bioszféra, benne az ember elemi reprodukciós köreinek felszámolását idézik elô.

A rákos sejtek módjára burjánzó nagytechnika és az ezt keretezó bürokratikus nagyszervezetek (technológiai változás) innovációkban öltenek testet, amelyek, akár a rákos daganatok az élő rendszereken, a „céltalan expanzió” ${ }^{19}$ erejével bírnak, rendkívül eltorzítva a természeti és a humánvilágot, benne az emberi pszichét, ad absurdum pusztulásra ítélve. A gondolat arra figyelmeztet, hogy az innováció, a nagytechnika, a technológiai változás aligha tartható az uralkodó globalokrata libertinus technofetisizmus $^{20}$ „mindent szabad” szellemi keretei között.

\section{A VOLUMENGAZDASÁGOSSÁG ELôTÉRBE KERÜLÉSE}

Emeljük ki a technológiai változás egyik különösen exponált elemét, a volumengazdaságosságot! ${ }^{21}$ A multi- és transznacionális vállalatok térnyerése különösen idôszerúvé teszi, hogy kritikai modellünkben a szakosodást, mint a technológiai változás egy eszközét kiemeljük. Megkülönböztetett figyelmet érdemel azért is, mert egy érdekes jelenségnek ad teret, talán a liberálsztálinizmus szókapcsolat írja le leghitelesebben a letûnt múlt eme reinkarnációját. A szakosodás okai között szokás megemlíteni az országok, régiók közötti termelékenységkülönbözôséget, az egyenetlen termelésitényezô-ellátottságot, a technológiai színvonal eltérését és a méretgazdaságosságot. ${ }^{22}$ A technika mindenhatóságát feltételezô közgazdászok még azzal is próbálkoznak, hogy a növekvố hozadékra ${ }^{23}$ építsék növekedési elméleteiket. A tökéletes piacot elótérbe állító neoklasszikus szintézis egyébként a csökkenô hozadékon alapul. A neokeynesiánusoknak nevezett - de az elemzés vonatkozásában inkább liberálsztálinista Krugman és Obstfeld a tökéletlen, pontosabban monopolpiacra építenek, a növekvô hozadékot feltételezik, s határozottan kiállnak e lehetôségek világgazdasági térnyerése mellett. A növekvô hozadék legfontosabb forrásának a volumengazdaságosság növekedését nevezik meg. Valójában minden innovációt (szervezeti, vezetési, múszaki, pénzügyi stb.) a volumengazdaságosságnak rendelnek alá.

De mirôl is van szó? A monopolisztikus verseny méretgazdaságossági előnyt leíró modelljében két feltétellel élünk: ${ }^{24} 1$. Számos cég van, de minden cég képes megkülönböztetni magát, pl. a személyautó-piac. 2. Egy cég terméke iránti kereslet függ: a) más hasonló termékek számától, b) az iparág többi cégének átlagárától. Legyen adott 
a keresletegyenlet: $\mathrm{Q}=\mathrm{S} \cdot\left[1 / \mathrm{n}-\mathrm{b} \cdot\left(\mathrm{P}-\mathrm{P}_{\mathrm{A}}\right)\right]$. Ahol: $\mathrm{Q}=$ a cég értékesítése, $\mathrm{S}=$ az iparág összes eladása, $\mathrm{n}$ = az iparág cégeinek a száma, $\mathrm{b}$ = állandó; árrugalmasság, $\mathrm{P}=$ a cég termékára, $\mathrm{P}_{\mathrm{A}}=$ a versenytársak átlagára. A cég így annál többet értékesít, minél kevesebb cég van az iparágban, s minél alacsonyabb árat állapít meg; tehát ha $n$ alacsony, és $\mathrm{P}<\mathrm{P}_{\mathrm{A}}$. Az iparág minden cége szimmetrikus; a keresleti és a költségfüggvény ugyanaz minden cég számára. A cégek számát (n) az átlagköltség és az árgörbe határozza meg. A cégek száma az átlagköltséggel egyenes, az árgörbével fordítottan arányos. Minél nagyobb n, annál kevesebbet adnak el, az átlagköltség nó, minél nagyobb n, az ár annál kisebb. A nemzetközi kereskedelem lehetőségének megnyílásával a piac mérete nô, a választék bôvül. Ne feledkezzünk meg arról, hogy minden vállalat termékei megkülönböztetettek, valójában tehát monopolszituációról van szó. A növekvô számú termelôk (növekvố termékválasztékot is jelent) a méretgazdaságosság révén egyre alacsonyabb áron értékesítenek. A gazdaságos üzemméret - ad absurdum - akkor jön létre a világgazdaságban, ha egy országban termelnek, s mindegyikben értékesítenek. A sztálinisták álma és a transznacionális cégek gyakorlata - a krugmani-obstfeldi modell szerint - egymásra talált.

A méretgazdaságosság a technológiai változás egy formája. Ha ilyen módon billen ki a termelési lehetôség határa $(0 \rightarrow 1)$, s a kvázimonopólium által alakított árarány $\left(\mathrm{P}_{\mathrm{C}} / \mathrm{P}_{\mathrm{F}}\right)^{3}$ végletesen növeli az isoértékvonal $\left(\mathrm{V}_{3}\right)$ meredekségét, akkor „belföld” közel kizárólagosan ruházati cikkek termelésére áll át, míg az élelmiszert közel teljes egészében importálják. A $\mathrm{V}_{3}$ isoértékvonalhoz rendelhetünk közömbösségi görbét, amelynek a $\mathrm{D}_{3}$ érintési pontja, ha lehet, még magasabb ruha- és élelmiszer-fogyasztást tesz lehetôvé (1. ábra).

További tanulság: a méretgazdaságosság érvényesítésével, mint a technológiai változás egy sajátos jelenségével számolva ismét az utilitarista szempont nyomul előtérbe, s egyfajta gazdasági totalitarianizmus (sztálini álom) is megvalósul. Különösen valósághúvé tehetjük modellünket, ha a két terméket nem két ágazatból, hanem ágazaton belül (intraindusztriális) választjuk. A krugmani-obstfeldi álomra egy fiktív példát is adunk: képzeljük el, hogy a közel 700 ezer lakosú kanadai Winnipeg körül annyi kenyérgyárat építenének fel, hogy az egész világnak itt sütnék a pékárut. Nem ismerünk olyan technikai gondot, amelyet a jelenlegi kollektív tudásunk mellett ne lehetne legyôzni. Winnipeg a gabonatermesztés központja, s a világ más tájairól is oda lehet szállítani a gabonát. A pékáruízlés kialakítását rá lehet bíznia a pszichológusokra, a marketingesekre és a médiára. A monopolcég innovációra fordított kiadásaival az esetleges kistermelôk aligha vehetnék fel a versenyt. A pékáru terítése puszta logisztikai kérdés; így a vegyszerekkel tartósított, az utolsó szállítási láncban elômelegített citromos-köménymagos (miért ne) kifli bármelyik fizetôképes reggeliző földlakó asztalára kerülhet. Ez volt Sztálin álma, s egy Nobel-díjas tudós, társával karöltve, a 21. század elején szolgáltatja hozzá az apologetikát!

A méretgazdaságosságon alapuló kereskedelem fontosságát Krugman és Obstfeld a következôkben foglalja össze. 1. A nagyobb piac miatt, a komparatív előnyön túl minden szereplő többletjövedelemhez, többletfogyasztáshoz jut. 2. Belföld csökkentheti a termelt termékek számát, s növelheti a belföldi választékot. 3. Az alacsonyabb 
fajlagos költségek révén nô a termelékenység. A méretgazdaságosság révén kialakuló világgazdasági termelési struktúra mögött véletlenek, az egyes cégek történelmi tradíciója áll. Ha a külkereskedelmi partnerek erôforrásaránya közel van, akkor az ágazatközi kereskedelem másodlagossá, a méretgazdaságosság viszont dominánssá válik.

A volumengazdaságosságon alapuló kereskedelem már egyáltalán nem elméleti konstrukció. Ez a libertinus-sztálini gazdaságszervezôdés a mindennapi valóság része, a vele járó „teszkó-paradoxon” jól mutatja a lényegét; a lokalitások, a régiók áruválasztéka relatíve bôséges, ugyanekkor ez a bôség a globális termékválaszték végzetes leépülését jelenti. Szemléletesebben: a szocializmus áruválasztékára még viszszaemlékezó évjáratok ámulva vehetik számba a szupermarketek termékkínálatát. Az „egy termelô minden országot lásson el” modell ugyanekkor világszinten látványos leépüléshez, választékszúküléshez vezet. A „teszkó-paradoxon” nem egy globalokrata libertinus lázálom, a tömegmédiában, a nézôként tömegeket vonzó sportágakban, az egyetemi oktatásban stb. hétköznapi gyakorlat. Pl. a Magyar Akkreditációs Bizottság revizorainak megfogalmazott elvárása szerint Magyarországon a felsófokú képzésben egységesen Paul A. Samuelson és William D. Nordhaus Közgazdaságtanát kell oktatni! A fó érv: mert az egész világon ebból tanulnak közgazdaságtant a fiatalok, s a majdani közgazdász világpolgárok egy közgazdasági nyelvet tudjanak beszélni. Ez a szemlélet az emberi létezés ontológiai alapjait kérdőjelezi meg, a szellemi, kulturális diverzitást, azt a teremtô erôt, amely oly színessé, gazdaggá tette a nemzeti és a helyi kultúrákat.

\section{KRUGMAN-OBSTFELD LIBERTINUS-SZTÁLINIZMUSÁNAK KÖVETKEZMÉNYEI}

Krugman-Obstfeld általános kereskedelemelméleti modelljének kritikája kapcsán felhívtuk a figyelmet az uralkodó szemléletú közgazdaságtan és gazdasági gyakorlat végzetes fogyatékosságaira; bírálat tárgyává tettük az uralkodó (utilitarista) érték- és célválasztás abszolutizálását, az „ízlésváltozás” eredményezte „fogyassz többet s többfélét” dogmát, a technológiai változás egyoldalú értelmezését, a volumengazdaságosságra alapozott globalokrata-libertinus álmot, az „egy cég termeljen bizonyos terméket minden fizetôképes földlakónak".

A nemzetközi kereskedelem David Ricardo korában a világ össztermelésének kb. 1\%-át tette ki, az alapvetô nyersanyagok s némi exkluzív jószág áramlott az országok között. A 19. század elején útjára induló exponenciális termelési és népességnövekedés nem hagyta érintetlenül a nemzetközi kereskedelmi forgalom és a világtermelés arányát, a század végére ez a szám kb. 4-5\%. Az exponenciális világtermelés- és a népességnövekedés képtelenségére felfigyeltek a legkiválóbb klasszikus közgazdászok (John S. Mill, Thomas R. Malthus), s a nemzetközi forgalomba kerüló tömegtermékek (pl. gabona) hatékony áramlása is előtérbe került (Robert Torrens, David Ricardo). Malthus és Mill pontosan látta: „véges térben nincs végtelen növekedés, sem a népesség, sem az anyagi gazdagodás terén”. Kritikájukban nem a létfeltételeket veszélyeztetô ökológiai gondok kerültek előtérbe. A reneszánsz, a felvilágosodás „legyőzzük a természetet” szellemi alapállása nem tette lehetôvé az ökológiai gondok felismerését, 
ezeket - odafigyelésre érdemesen - a 20. század második felében nevezték meg a szakemberek,${ }^{25}$ inkább az erôforrások végessége és az aggasztó társadalmi következmények szerepeltek. A klasszikusokat a népességnövekedés indukálta élelmezési gondok foglalkoztatták. Vajon rendelkezésre állnak-e a tömegek élelmezéséhez elengedhetetlenül szükséges erôforrások (pl. szántók, tengerek)? A gazdasági növekedés mögött álló munkamegosztás parttalan tagolódásában Adam Smith és Karl Marx tökéletesen látták a társadalmi veszélyeket. Elsôként Marxot idézzük: „...általános szabályként megállapítható, hogy minél kevésbé irányítja a tekintély a munkamegosztást a társadalmon belül, annál jobban kifejlődik a munkamegosztás az üzemen belül, és annál inkább alá van vetve egyetlen ember tekintélyének. Eszerint a munkamegosztás szempontjából a tekintély az üzemben és a tekintély a társadalomban fordított arányban állnak egymással" (Marx, 1973:337). Ez utóbbi mondat fényében válik érthetôvé a modern ember skizofréniája. A munkahelyén speciális tevékenység révén - s ezen a gyáripar, az automatika, a számítógép sem segít - az ember olyan beszúkült lesz, olyannyira mûveletlen és szellemtelen, amennyire az „még emberi lény”-nél lehetséges. Ez a szellemileg korlátozott lény ráadásul közvetlenül a gép, végsố soron egy zsarnok (fốnök) szolgája. A gyárkapun, a hivatalból kilépve viszont belecsöppen a liberálisok/libertinusok teremtette „szuverenitásba és szabadságba”, abba a köré vont virtuális világba, amely gigászi méretúvé növelte a manipulációt. Itt egyetlen kérdés vetôdik fel: mi lesz abból, ha a lelketlenség szuverenitásra, szabadságra jut, a butaság pedig gondolkodni kezd? Smith ezzel is számolt: „A munkamegosztás fejlődésével a munkájukból élook legnagyobb részének, azaz a nép nagy tömegének foglalkozása gyakran csak néhány, egy vagy két igen egyszerú múveletre korlátozódik. A legtöbb ember képességeit azonban rendes foglalkozása alakítja. Annak az embernek, akinek egész életét néhány egyszerú mûvelet végzése tölti be, amely múveletek eredménye is talán mindig vagy csaknem mindig ugyanaz, nincs alkalma, hogy képességeit kifejtse, és hogy találékonyságát oly nehézségek eltávolítására használható eszközök kieszelésében gyakorolja, amely nehézségek munkájában sohasem következnek be. Természetes tehát, hogy elveszti az ilyen szokások gyakorlatát, és általában olyan tudatlan és ostoba lesz, amilyen emberi lény csak lehet” (Smith, 2011:328-329). Az elmúlt több mint kétszáz év technikai-szervezeti változásai a munkamegosztásban, ha lehet, még nagyobb torzulást idéztek elő. Miközben az uralkodó ideológia nem gyốzi hangsúlyozni az individualizmus fontosságát, a gazdaságban ez brutális egoizmusként van jelen, a tagolt munkamegosztás tökéletesen elszakítja a dolgozó embert a végsố produkció létrehozásának élményétôl, ráadásul el kell fogadnia az abszolút manipulatív módon szorgalmazott „egy csapat vagyunk”, „team”-et alkotunk szociálpszichológiai „kezelést”. Az így kialakult kényszerú munkatevékenységek állandósult képmutatásra, tehát meghasonlásra kényszerítik a munkavállalók tömegeit. De nem ez a legnagyobb csapás! Az új globalokrata libertinus ideológia szerint a mesterséges intelligencia képességével felruházott robotok, informatikai adathordozók kiválthatják munkájából a modern kor alanyát, a gyarlónak, setesutának bizonyuló hús-vér embert, egyszóval megfosztják szakmai identitásától is. ${ }^{26}$

A külkereskedelem révén bóvülố fogyasztás modelljei meglehetôsen mostohán kezelik az ún. transzferköltségeket (a vámokat, az engedélyek többletkiadásait, a de- 
vizaelszámolás terheit stb.), de ezekről valóban elmondható: a lényeget nem érintik, legfeljebb néhány százalékkal szúkül a komparatív elôny. Általánosan elfogadott, hogy a szállítási költségeket is ebben a szellemben kezelik, s ez a szemlélet viszont végzetes eltévelyedés forrása. Nem is elsôsorban azért, mert a szállítási költség jelentôs, hanem azért, mert nem számolnak a szállítások súlyos következményeivel, a negatív externáliákkal. Errốl még az említett, a világ egyik elsố számúnak tartott, 872 oldalas egyetemi kézikönyvében sincs szó. ${ }^{27}$ Elvégre a közlekedés nyomában lepusztuló litoszférában, atmoszférában, hidroszférában nem vagy csak nagyon nehezen ragadhatók meg az okozott károk. A negatív externáliák közé sorolhatjuk továbbá a balesetek, a zajártalom többletkiadásait. A közutakon folyó embercsempészet, prostitúció, kábítószer-kereskedelem döntô része a komparatív előnyt „hordozó” közlekedési eszközökhöz kötôdik, a kamionokhoz, a vasúti vagonokhoz, a teherhajókhoz, a repülógépekhez. Ezek rendvédelmi „kezelése” is levonandó a realizált komparatív előnyből; amit tehát nyert a termelő, a kereskedő és a fogyasztó az egyik oldalon, azt, sôt esetenként annak végzetesen többszörösét elveszítik ugyanôk, amikor adóznak, amikor a klímaváltozás, a helyi közlekedés, a migráció stb. okozta kihívásokkal nap mint nap küzdenek. Az eddigi bôséges negatív externáliák adatolását feleslegesnek érezzük, evidenciának tekintjük, ráadásul a komparatív előnyök dogmájának, illetve gyakorlatának a legsúlyosabb következményeit még mindig nem említettük! Gondoljunk a pár óra alatt a Földön szétteríthetô baktérium- és vírusfertôzések okozta ártalmakra, de még inkább a helyi közösségek, régiók szétzilálásának gondjaira (lásd a mottót, Keynes ezúttal is zseniális gondolatait!). Ez utóbbiak már nem illeszthetốk a legtágabban vett költség-haszon kalkulusba, itt a létfeltételeket ostromolja a primitív homo oeconomicuson alapuló közgazdászi emberkép, az erôsen fogyatékos utilitarizmus, a pszeudo-piacgazdaság, illetve az ezer sebbôl vérzô komparatív elônyök dogmája. Ezúttal csak az utóbbit kívántuk nyilvánvalóvá tenni.

\section{ÖSSZEFOGLALÁS，TÁRSADALMI IMPLIKÁCIÓK}

A dolgozatban arra a kérdésre kerestük a választ, hogy az uralkodó nemzetközi gazdaságtan egyik legismertebb kézikönyvében Krugman és Obstfeld milyen kimondott és ki nem mondott előfeltevéseken keresztül jut el a közgazdaságtan szakállas dogmájának megerôsítéséhez. A szintetikus igényú modell végsố célja Krugman és Obstfeld világgazdasági víziójába torkollt. Itt az ideje - üzenik a szerzók -, hogy a korunk legfontosabb komparatív előnyök forrását jelentô mechanizmusa, a volumengazdaságosság új világgazdaság-szervezôdési formának adjon teret. Nevezetesen: „az egy cég termeljen a világ minden fizetôképes földlakójának egy bizonyos terméket” kora jött el. Ez a mikroökonómiai konklúzió könnyen átfordítható makroökonómiába, illetve nemzetközi gazdaságba: itt az ideje, hogy újabb lépéseket tegyen az emberiség a világállam létrehozatala irányába. ${ }^{28}$

Kritikánk arra irányult, hogy ezt a szellemi (gazdasági és gazdaságelméleti) és morális eltévelyedést a saját fogalmi keretei között leplezzük le. A Krugman-Obstfeld-modell szinte minden eloofeltételérôl, minden elemzés tárgyává tett, modellbe 
vont jelenségéról - megítélésünk szerint - szinte játszi könnyedséggel kimutattuk, hogy egyoldalú, téves, esetenként elemi filozófiai antropológiai, ontológiai, axiológiai, etikai normákat sért. E konklúzió megfogalmazásában a legkiválóbb klasszikus közgazdászokat és a modern kor legkiválóbb civilizációkritikusait (világnézeti alapállásuktól függetlenül) követhettük.

Az utilitarizmus (fogyassz többet és többfélét) Bentham után a nyugati társadalom gazdaságszerveződésének alapelvévé vált; dicsôségesebb korok (a görögöktôl egészen a 19. század elejéig) pontosan ismerték az utilitarizmust, láták magyarázó erejét, de látták korlátait is, így nem vált egyetlen komoly szellemi áramlat attribútumává sem. A közgazdaságtanban a szubjektív határhaszon-elmélet viszont sikerre vitte s a mai napig mérgezi általa a világ szellemi életét és gyakorlatát.

A világgazdaság erôviszonyai mögött az outputok/inputok árarányainak átrendezôdése áll, és vice versa. A fékevesztett népesség- és gazdasági növekedés az utilitarizmussal megfertôzött világgazdaság nemzetgazdaságaiban, régióiban bőségesen kitermelik az outputok/inputok árarányváltozásait, s ez kellóen motiválja a gazdasági szereplôket, hogy törekedjenek az új és legújabb komparatív elôny kínálta lehetôségek kihasználására. Az elmúlt kétszáz évben abnormálissá duzzadt világnépesség és gazdasági potenciál a rendkívül problémás technológiai változással „olajat önt a túzre”, s tovább táplálja a globális veszélyforrásokat, a Föld ökoszisztémájának tönkretételét, a társadalmi együttélési viszonyok szétzilálását és az emberi psziché összezavarodását. Itt a legelemibb logikai szabályok is sutba kerülnek. Az uralkodó technokrácia arctalan képviselôii, a gyakorlati szakemberek nem gyốzik hangsúlyozni a technológiai változás szükségszerúségét. Noha Hésziodosztól Heideggerig a legkiválóbb gondolkodók - világnézeti alapállásuktól függetlenül - épp az ellenkezôjére figyelmeztetnek. Nincs itt szó semmiféle szükségszerúségrôl, de kollektív butaságról s e butaság leple alatt egy szúk csoport hatalmának érvényesítésérôl annál inkább. Søren Kierkegaard idôben, a kapitalizmus hajnalán felhívta a figyelmet a technika mindenhatóságát vallók érvelésének elemi logikai hibájára: „Minden, ami keletkezik, éppen keletkezése révén bizonyítja, hogy nem szükségszerú; mivel a szükségszerú az egyetlen, ami nem keletkezik, mert a szükségszerú van" (Kierkegaard, 1997:99-100).

A néhány évtizedes, legfeljebb alig több, mint százéves emberléptéket vesztett (mert túl gyors, mert túl nagy, mert pusztítóan tömegszerû) nagytechnikák (atomenergia, biotechnika, kemikáliák, informatika stb.) ad absurdum szükségszerúségéról beszélni olyan fokú kommunikációs torzulás, amely a „Nagy Reccs”-ek egyik okává válhat. A nagytechnikák aggasztó ökológiai, társadalmi és individuális következményeiről már szóltunk.

Krugman és Obstfeld az új növekedéselmélettôl kölcsönözve a gondolatot, a volumengazdaságosságtól növekvố hozadékú gazdaságot és ennek megfelelố világgazdasági rendet vár, és ebbôl következôleg a technika megszállottjaival karöltve, az újabb és újabb ipari forradalomtól (napjainkban az informatika innovációiban a negyedik ipari forradalmat látják) a kánaán beköszöntét ígérik. A gazdaságtörténeti tények viszont arról árulkodnak, hogy minden eddigi ,ipari forradalom” világszinten soha nem látott vagyoni különbségeket szült, az abszolút és a relatív nyomorgók, éhezốk lélekszáma, 
illetve aránya pedig egyre nagyobb lett. ${ }^{29}$ A méretgazdaságosság mint a technológiai változásnak egy uralkodóvá váló megjelenési formája olyan fokú kulturális diverzitásvesztést indított útjára, amely az emberi létezés ontológiai alapjait kísérli megrendíteni. Csíraszerú jelenvalóságát „teszkó-paradoxonnak” neveztük, s libertinus-sztálini jelenségnek tartjuk. A képtelennek tûnố fogalompárosítás húen tükrözi Krugman és Obstfeld általános kereskedelmi modelljének természetét; a tökéletes világgazdasági piac kezdeti előfeltevésétôl a modell kifejtése során bontakozik ki - a szerzópárost követve - az „egy cég termeljen egy terméket a világon” elképzelés. Itt már csak a helyettesíthetô termékek monopóliumai között értelmezhetô a verseny, s mivel itt a szereplők száma erôsen korlátozott, rövid idô alatt lejátszódhatnak a fúziók, a valódi szupermonopóliummá válások. A monopóliumok közötti harcnak ezzel még nem lenne vége. A harc az oligarchák között azért folyna, hogy milyen jószágokból álljon össze az identitásától megfosztott, „biomasszának” tekintett tömegember fogyasztói kosara. E harc konszolidálását lenne hivatott a világállam biztosítani.

Az uralkodó közgazdaságtan apologétáinak törekvései mögött a világállam gazdasági és technikai szükségszerúségének felettébb ingoványos, legfeljebb szúk csoportérdeket (oligarchák) szolgáló indokai állnak. Ezt a minden elemében problémás, globalokrata libertinus gazdasági szemléletet ezúttal saját fogalmi bázisán lepleztük le. Az autarkia fontosságát elôtérbe helyezók (pl. Keynes, Daly) a Krugman-Obstfeld-féle globális törekvésekkel szemben pontosan az ellenkezó irányt jelölik meg: a világ dezintegrációja, a regionalitás előtérbe helyezése hordozhat csak emberi világot, minden filozófiai antropológiai, ontológiai, gnoszeológiai, axiológiai és etikai megfontolás ezt igazolja, ezt követeli a hatékony szabályozás, a szabályozók és a szabályozottak emberléptékú távolsága is. A görögök ebben a vonatkozásban is megkérdôjelezhetetlen támpontokat hagytak örökül. Arisztotelész politikai (társadalmi) és gazdasági szempontból vizsgálta, mekkora lehet az optimális népességú polisz: „...a legfontosabb az, hogy annyi lakos legyen, amennyi a politikai közösségnek megfelelően rendelkezik a boldog élethez szükséges autarkeiával, bár lehetséges, hogy vannak ennél súrúbb lakosságú, nagyobb városállamok is, de ez, mint mondottuk, nem mehet a végtelenségig. Hogy pedig mi a fokozásnak a határa, azt tapasztalatból könnyen megítélhetjük. A városállami tevékenység ugyanis részint a vezetôk, részint az alattvalók dolga - éspedig a vezetố feladata a rendelkezés és a bírói döntés; ahhoz azonban, hogy valaki igazságosan döntsön, és hivatalát méltón betöltse, feltétlenül szükséges, hogy a polgárok elismerjék egymás képességeit, hiszen ha ez nem áll fenn, ott szükségképpen rosszul mennek a hivatali és bírói ügyek. Egyik téren sem igazságos a vaktában való döntés, ami pedig a túlnépesedésnél nyilvánvalóan bekövetkezhetnék” (Arisztotelész, 1984:284). Az idézett szöveg az optimális lélekszámú polisz kritériumául az autarkia (autarkeia) társadalmi szempontját helyezte előtérbe. A társadalmi viszonyok akkor lehetnek hitelesek, akkor érvényesülhet a közösség kohéziója, és akkor biztosítható az igazságosság, ha a polgárok vertikális és horizontális kapcsolataiban érvényesül az ember és ember közötti közvetlenség. Az autarkia gazdasági aspektusa arra a területre utal, amely biztosítja a polisz gazdasági jólétét („...ha a föld mindent megterem; ...ha mindenünk megvan, és semmiben sem látunk szükséget”); kiterjedésre és 
nagyságra pedig akkora legyen, hogy a rajta élók kényelemben élhessenek, szabadon és mértékletesen” (Arisztotelész, 1984:284). Az optimális népességú településeknek Arisztotelész szerint egyetlen kritériuma van, az autarkia, amely két nézópontnak kell hogy megfeleljen: társadalmi szempontból biztosítsa a közvetlenséget, gazdasági szempontból pedig az önellátást. A közvetlenség intenzitása a települések lélekszámának növelésekor csökken, az önellátás viszont a terület, illetve a lélekszám növekedésével nô. A két „függvény” optimuma nyilván a metszéspontban van, ez a humánetológusok szerint kb. 1200-30 000 fốt jelent (Csányi, 1999, 8. fejezet). Ezt az optimumot a világ népességszámának növekedése és az új kommunikációs technika lényegében nem érinti. (A metropoliszok még emberinek nevezhetô múködését is az 1200-30 000 fôs közösségi fürtök létezése tartja csak fenn. ${ }^{30}$ )

A globalokrata libertinus hatalomgazdaság logikája szerint mindaddig érdemes szakosodni, amíg az érintett eladók és a vevook - egy elôzô állapothoz képest - szúk piaci értékelés szerint jól járnak. A világkereskedelem történetében mindig ez a megfontolás motiválta a termelôt és a megrendelôt, illetve a közvetítô kereskedôt is. Az alapanyagok, az alkatrészek, a félkész termékek termelési láncok szerinti bolyongása úgy fejezôdik be, hogy valamelyik transznacionális vállalat védjegyével jegyzett késztermékként megtalálja a világ számos pontján a végsố fogyasztót. A világkereskedelemben három korszakot határolhatunk el.

- Az ókori kezdeti idóktôl a tömegtermelés koráig (gabona, bor, só, fa, kalikó, kötél stb.) és az exkluzív javak (fúszer, selyem, arany, ezüst stb.) kereskedelmére koncessziókat adott a mindenkori hatalom. Pl. a Krím félszigetrôl Attikába érkezô búza speciális intézményi keretek között (empórosz) kerülhetett a fogyasztóhoz (Polányi, 1984, 6. fejezet). A felfedezések korától a velencei, a genovai, az antwerpeni, az amszterdami, majd angol hajók olyan szövetségek, társaságok keretei között múködtek, amelyek mögött az uralkodók, késôbb nagy hatalmú városi tanácsok, végül kormányok álltak. A 17-18. században a világkereskedelem centruma Velence, Genova ellenôrzése alól átkerült Flandriába, kivált Amszterdam játszotta a főszerepet. „1666-ban az amszterdami tôzsde tôkéjének háromnegyed része a Keleti-tengeren lebonyolódó kereskedelmet szolgálta, és csak negyed része állt az indiai kereskedelem részére. Ugyanebben az idóben a Keleti-tengerre kifutó száz hajóval szemben Kelet-India felé csak egy vitorlázik el” (Homonnay, 1946:59). A hajók teljesítményérôl - Fernand Braudel becslése alapján - annyi mondható el, hogy Európa a 17. század elején kb. 600-700 ezer tonnát képviselő hajótérrel rendelkezik, a 18. század végére ez a szám megötszöröződik (kb. 3372 ezer tonna), évi három fordulót feltételezve ez kb. 10 millió tonna forgalmat jelentett, s ez egy mai nagy tengeri kikötố forgalmának felel meg. ${ }^{31}$ Korábban már jeleztük, hogy a kapitalizmus hajnalán a világtermelés alig több, mint egy százaléka került csak nemzetközi forgalomba.

- Az ipari forradalmat (gózgépek) követóen továbbra is a tengeri kereskedelem játssza a fốszerepet, a klasszikus tömegáru (gabona) mellett megjelenik az új energiahordozó, a szén, a vasutak épülésével a vasáru. A forgalmat továbbra is csak az óriáscégek bonyolítják. A 19. század végére a világtermelés 4-5\%-a kerül nemzetközi forgalomba. 
- A harmadik ipari forradalom (az elektromosság, a robbanómotorok, a kemikáliák, a biotechnika, az informatika kora) teremti meg a 20. században, hogy a nélkülözhetetlen alapanyagokon és energiahordozókon túl a gépek, a jármúvek és a fogyasztási cikkek is útra keljenek a komparatív előnyök realizálásának reményében. (A gazdaságtörténeti húség megköveteli azt a megjegyzést, hogy ez az expanzió valójában a 20. század második felében bontakozott ki, a 20. század elsô felének két világháborúját jelentôs részben a létfontosságú energiahordozók és ásványi anyagok feletti hatalom újraelosztásának igénye motiválta.)

Napjainkban a világtermelés valamivel több mint 20\%-a kerül nemzetközi forgalomba. Formálisan továbbra is a nemzeti kormányok szabályozzák a nemzetek közötti áru-, tôke- és munkaerô-forgalmat. Valójában viszont a nemzetek által létrehozott s a 20. század második felében kvázi önállósodott nemzetek feletti szervezetek (WTO, Világbank-csoport pénzintézetei, Európai Unió stb.) játékszabályai érvényesülnek, s ezeket a játékszabályokat a nemzetközi áru- és tôkeforgalom döntô részét adó multiés transznacionális cégek igényeihez igazítják (a multi- és transznacionális társaságok között a megkülönböztetett szerepet a világot behálózó pénzintézetek játsszák). Tevékenységük nyomában jár az egységes jogszabályi és intézményi rendszer kialakításának igénye, az infokommunikáció glóbuszt behálózó rendszerének kiépítése, a közlekedés határtalan kiterjesztése, s vele a természet reprodukciós köreit szétziláló negatív externáliák szétterítése, a szükségletek világszintû́ uniformizálása (teszkó-paradoxon), a munkamegosztás embert felparcellázó, értelmes - produkcióhoz kötött - munkatevékenységtôl való megszabadítása, a munkaerô globális léptékú mobilizációra kényszerítése révén az ember gyökértelenítése stb. Ezek lennének - közelítésünkben - a globalizáció hátrányai. S ezzel szemben - a Krugman-Obstfeld-modellt követve - valójában egyetlen „pozitív” érv hangzik el. A komparatív eloonyök érvényesülése révén az emberiség fogyasztási szintje emelkedik, s ez az emelkedés egyben a szuverén világpolgárok szabad választását is garantálja. Ha ez utóbbiakban lenne némi igazság - tényszerúen igyekeztünk bizonyítani, hogy nincs -, akkor is maga alá temetnék a globalizmus ellen felsorolt érveink. A globalizációban, végsố soron a világállam létrehozatalában érdekelt libertinus oligarchák süketté váltak az ellenérvekre, és vakká a határtalan mikroszakosodás és makrointegrálódás hátrányaira, esetenként életellenességeire. Több évszázados helyi közösségeket, több millió éves ökoszisztémákat tesznek tönkre azok a multi- és transznacionális cégek, amelyek Afrika, Ázsia, Latin-Amerika, Kelet-Európa erôforrásaira s fôként olcsó munkaerejére építve szorgalmazzák a szakosodást. A globalizmusban érdekeltek anyagi támogatását élvezik azok a hangadó kulturális rétegek, amelyek az így kialakult világállapotot mint multikulturalitást, mint posztmodernt, mint a libertinus társadalomszervezési rendet apologetizálják. Azok az ellenvetések, amelyek a globalizmust alapelveiben kérdőjelezik meg - bármennyire legyenek beláthatóak -, újból és újból megfogalmazásra és érvényesítésre várnak.

A globalokrata libertinus hatalomgazdaságban természetesen már nem is a gazdaságon van a hangsúly, ellenkezóleg, a gazdaság csupán a hatalom eszköze. A hatalom „thümosza” (önérvényesítése) pedig a médiákban, minden idôk egyik legproblematikusabb emberi nagytechnikájában, különösen hatékonyan érvényesíthetô. 
Gondosabb közgazdasági elemzések időben felhívták a figyelmet az ún. modern kor (1789-tôl, a nagy francia forradalomtól számítva a modern kort) veszélyeire. Az elmúlt valamivel több, mint kétszáz év zsákutcájában a legkiválóbb civilizációkritikusok figyelmeztetései is önmagukért beszélnek. A viszonylag rendezett szerves sokszínúség - az emberiség több ezer éves kultúráira gondolunk - kitermelték azokat a védekezési módokat, amelyek azonnal múködésbe léptek, ha egy-egy régiót, nemzetet, birodalmat támadás ért. A világállamot célzó globalizmus a rendezett szerves sokszínúség helyére a rendezett egynemúséget ígéri, így fennáll annak a veszélye, hogy az emberiség a még emberinek nevezhetô kulturális küszöb szintje alá süllyed.

A reményrôl is szóltunk: a nemzetállamok világállamba szervezódésének törekvésével szemben - a filozófiai antropológiai, az ontológiai, az axiológiai, az etikai, az ökológiai és humánökológiai evidenciák alapján - a szuverén, közös érdekú nemzetállamok s ezek régiói kell hogy előtérbe kerüljenek. Jó példa a Visegrádi Együttmúködés ilyen irányú törekvése. A lokalitások, az értelmes életterek és tartalmas életvilágok irányába indulva reménykedhetünk csak a gaia-ökoszisztéma egészségének visszaállításában, a társadalmi együttélési viszonyok sokszínúségének megőrzésében és az emberi psziché egészségének redivivuszában.

\section{JEGYZETEK}

$1 \quad$ Idézi Daly-Cobb, 1989:209.

2 Lásd Balogh, 1994; a 9. fejezet tárgyalja keynesiszta alapon a nemzetközi gazdaság és a világgazdaság fonákságait.

3 Közelítésünk ugyan a nemzetközi kereskedelemre összpontosít, de a nemzetgazdaságok keretein belül is a komparatív előnyök mozgatják az áruforgalmat, s itt is fennállnak kritikai általánosításaink.

4 Nemzetközi gazdaságtani kérdések elemzéséért Nobel-díjat kapott (2008) közgazdász.

$5 \quad$ Lásd részletesen $A$ külkereskedelem alapmodellje címú alfejezetet.

${ }_{6}$ A komparatív elônyök alapmodelljeire építő, ezeket finomító elképzelések száma meglehetôsen magas, itt csak felhívjuk a figyelmet néhány neofaktor-elméletre: Raymond Vernon termékéletciklus-elméletére, Staffan B. Linder keresleti tényezôket hangsúlyozó elképzeléseire, Michael E. Porter ún. gyémántmodelljére (ez utóbbi a kompetitív elônyök praktikus osztályozását adja, de ezek egyben a komparatív elónyöket is jelentik).

7 Az isoértékvonal az azonos nemzetikibocsátás-értéket képviseló jószágkosarak halmazát jelenti; matematikai eszközökkel élve: egy kétjószágos térben lineáris függvényként ragadjuk meg (lásd az 1. ábrát).

8 A termelési lehetôség határa a rendelkezésre álló erôforrások optimális kombinációja melletti outputok kombinációjának halmaza.

9 A „szuverén fogyasztó” az uralkodó neoklasszikus szintézist képviselô közgazdászok modelljeiben egy rendíthetetlen sztereotíp prekoncepció. Tarthatatlansága nyilvánvaló, elég, ha felhívjuk a figyelmet Philip Kotler „néhány” általános kommunikációs és promóciós eszközbốl álló katalógusára: 16 reklámtechnikával (nyomtatott és audiovizuális reklám, csomagolás melléklete, postázás, mozgókép stb.), 13 értékesítési ösztönzéssel (verseny, játék, áruminta-bemutatás, szórakoztatás stb.), 6 propagandamódszerrel (sajtótájékoztató, szemináriumok, PR stb.), 6 személyre szabott értékesítési eljárással (bemutató, telemarketing, ügynöki áruminták stb.) ostromlott a „szuverén” fogyasztó. Kotler, 1988:46.

10 A szubjektív határhaszon-elméletben a közömbösségi görbe az azonos összhasznú jószágkombinációkat tartalmazza.

11 A szubjektív határhaszon-elmélet az utilitarizmuson alapszik. Az emberiség kultúrtörténetében nem ismerünk olyan korszakot (görögök, Római Birodalom, skolasztika, reneszánsz), ahol az utilitarizmust 


\section{Polgári Szemle · 14. évfolyam 1-3. szám}

általános társadalom- és gazdaságrendezô elvként fogadták volna el, de még a liberális korszak jelesei is tarthatatlannak látják az utilitarizmus abszolutizálását (lásd errôl Rawls, 1997). Ezzel szemben az uralkodó közgazdaságtan megkérdőjelezhetetlenül ragaszkodik ehhez az alapálláshoz. Az áttörés a 19. század elején született, Jeremy Bentham nevéhez szokás kötni. A szubjektív határhaszon-elmélet bírálatát lásd részletesen Somogyi, 2015, 1. fejezet.

12 A „homo oeconomicus” közgazdaságtani primitív emberkép a 19. század elején a zsurnalizmus világában született, rendületlenül tartja magát korunk új neoklasszikus szintézisében is. Bírálatát lásd Petôné Csuka-Majoros-Somogyi, 2008.

13 Az új gazdaságszervezôdési mód (a kapitalizmus) csak a 19. század közepén kapott nevet. A protokapitalizmus gyökérvilága természetesen a korai reneszánszban is kimutatható.

14 Thomas R. Malthus híres munkájának elsố változata 1798-ban jelent meg, itt az 1803-ban kiadott bôvített, javított kiadásból idéztünk. Idézi Semlyén, 1982:61-62.

15 Bentham, Jeremy (1970): An Introduction to the Principles of Morals and Legislation [1789]. Ed. J. H. Burns and H. L. A. Hart, The Athlone Press, London. Magyarul: Bentham, 1977. A görögök, a skolasztika, de korunk legnagyobb gondolkodói (John Rawls, Martin Heidegger stb.) számolnak az utilitarizmussal, de elutasítják annak lehetôségét, hogy az utilitarizmus fundamentális társadalom- és gazdaságrendezó alapelv legyen. A neoklasszikusok, illetve az új neoklasszikus szintézis, tehát az uralkodó közgazdaságtan - ezzel szemben - rendületlenül az utilitarizmuson alapul!

16 Technológiai változáson mindazon szervezési, vezetési, múszaki, pénzügyi, marketing, logisztikai stb. újítást (innovációt) értve, amelynek során egy gazdasági rendszer - itt nemzetgazdaság - hatékonysági szintje emelkedik. Jeleztük, hogy vannak olyan átrendezôdések, amelyek nem járnak hatékonyságszint-emelkedéssel. E fejezet végén pedig arra hívjuk fel a figyelmet, hogy a technológiai változás gazdasági hatásán túlmutató következményei végzetesen pusztítók is lehetnek, kivált ökológiai, társadalmi és az emberi psziché vonatkozásában.

17 Az idézet a Munkák és napok címú múbôl származik.

18 Martin Heidegger technikakritikáját hitelesen interpretálja Friedrich-Wilhelm von Herrmann a Technika, politika és múvészet a Beiträge zur Philosophie-ban címû elôadásában. Idézi Fehér, 1991:39-58. Lásd továbbá Heidegger, Martin (1953): Kérdések a technika nyomán. Idézi Tillman, 2004. Ugyanezt a hangot képviselik a legjelesebb liberálmarxisták is, Habermas, 1954 vagy Marcuse, 1990.

19 J. Habermas idézetéból kiemelve. Az eredeti szöveg így hangzik: „A technikai fejlôdést a perfekció dinamikája hajtja elôre. E fejlôdés a céltalan expanzió jellegével bír, amely egyúttal eltávolít a dolgokkal való kapcsolatgazdag, szemléletesen ellenórizhetó bánásmódtól - azaz eltorzítja a világot” (Felkai, 1993:16).

20 A globalokrata libertinus technofetisizmus kifejezésben a „globalokrata” arra utal, hogy döntô részben egy „csinált” mechanizmusról van szó, a libertariánus oligarchiák csinálmányáról; a libertinus kifejezés az egyébként is problémás liberalizmus elfajzására utal; a technofetisizmus mögött pedig az individualitást, a személyességet, a közvetlenséget, az autentikus közösségiséget (ezek közelítésünkben nem egymást kizáró fogalmak, ellenkezôleg, mértékek között értelmezve kölcsönösen feltételezik egymást) negáló törekvések állnak.

21 A kiemelést az indokolja, hogy a volumengazdaságosság gazdasági hatékonyságszintet emelő hatásán túl (ez vált a gazdasági növekedés legfőbb elemévé) az ökológiai és társadalmi következmények számbavétele különös figyelmet követel. A volumengazdaságosság növekedése egyébként akkor következik be, ha a termelés volumenének növelése során a fix költségek állandók, vagy kevésbé növekednek a változó költségek mellett.

22 A méret- és a volumengazdaságosság szinonim fogalmak.

23 A növekvô hozadék azt jelenti, hogy azonos befektetésnövekmény egyre nagyobb hozadékkal jár. Meyer Dietmar az ún. új növekedési elmélet ismertetésekor hívta fel e törekvésre a figyelmet (Meyer, 1995). A hagyományos, illetve az uralkodó közgazdaságtan a csökkenô hozadékra épít, tehát azonos befektetésnövekmény jellemzôen egyre kisebb hozadékot eredményez.

24 Krugman-Obstfeld vulgáris modelljét követjük, ezáltal is szeretnénk láttatni, hogy milyen ingatag lábon állnak azok az érvek, amelyek az ún. világállam-koncepciót vannak hivatva direkt vagy implicit módon megalapozni. Lásd Krugman-Obstfeld, 2003, 6. fejezet. 


\section{Somogyi Ferenc: Komparatív elönyök, ökológiai ártalmak, társadalmi károk...}

25 Az elsôséget sokan Rachel L. Carson könyvének tulajdonítják. Lásd Carson, 2007.

26 Aleksandr Dugin orosz gondolkodó különösen nagy meggyốzố erôvel írja le a libertinus ideológia fasizmust, bolsevizmust felülmúló eme elfajzását. Lásd: A. Dugin köszönti könyvének magyar kiadását. www. youtube.com/watch?v=35pnicW63rk\&t=39s. Továbbá Dugin, 2017, 11. fejezet.

27 Krugman-Obstfeld elemzett munkája egy ízben említ egy „visszataszító” példát, ti. az USA azért „akadékoskodott” a mexikói tôkehalimport kapcsán, mert a mexikóiak delfineket veszélyeztetô módon halásztak a tôkehalakra. (A félreértések elkerülése végett: Krugman és Obstfeld az USA eljárását ítéli felháborítónak!) Lásd Krugman-Obstfeld, 2003:267.

28 Krugman-Obstfeld modelljének bemutatásakor az elôfeltételek, a levezetések vonatkozásában rabszolgai módon követtük a szerzópárost, a következtetések végiggondolásában viszont olyan heurisztikai utat választunk, amely segíti nyilvánvalóvá tenni a modell igazi üzenetét, s ennek fényében könnyebb lesz megérteni elsôsorban Krugman nagy hatású publicisztikai tevékenységét. Lásd errôl a világ széles nyilvánosságának íródott infantilis címú, tendenciózus üzenetû könyvét (Krugman, 2012).

29 Meyer Dietmar felhívta a figyelmet, hogy a növekvô hozadékon alapuló gazdaságelmélet felszámolná a csökkenô hozadékra épülô, U alakú költségfüggvényekre alapozó, szubjektív határhaszon-elméletet. A világállam víziójában gondolkodó embernek persze ez bagatell áldozat lenne (Meyer, 1995).

30 Csete György építész személyes közlése 1995-ben.

31 Braudel, 1985:360-361, tartalmi idézet.

\section{FELHASZNÁLT IRODALOM}

Arisztotelész (1984): Politika. Gondolat Kiadó, Budapest.

Balogh Tamás (1994): Mit ér a hagyományos közgazdaságtan? Közgazdasági és Jogi Könyvkiadó, Budapest.

Barócsi Zoltán - Somogyi Ferenc (2010): Mit hordoznak a régiók? In Beszteri Béla - Majoros Pál - Zimler Tamás (szerk.): Magyarország határ menti térségeinek és városainak fejlôdése a rendszerváltás és európai uniós tagságunk következtében. MTA VEAB, Veszprém.

Bentham, Jeremy (1977): Bevezetés az erkölcsök és a törvényhozás alapelveibe. In: Márkus György (szerk.): Brit moralisták a XVIII. században. Gondolat Kiadó, Budapest.

Bogár László (2003): Magyarország és a globalizáció. Osiris Kiadó, Budapest.

Braudel, Fernand (1985): Anyagi kultúra, gazdaság és kapitalizmus, XV-XVIII. század. A mindennapi élet struktúrája. Gondolat Kiadó, Budapest.

Brzezinski, Zbigniew (1999): A nagy sakktábla. Amerika világelsôsége és geostratégiai feladatai. Európa Könyvkiadó, Budapest.

Carson, Rachel (2007): Néma tavasz. Katalizátor Könyvkiadó, Páty.

Chrudinák Alajos (2014): Ukrajna. Amerikai-orosz konfliktus. Magyar Fórum, május 8.

Csányi Vilmos (1999): Az emberi természet. Vince Kiadó, Budapest.

Daly, Herman E. - Cobb, John C. (1989): For the Common Good: Redirecting the Economy Toward Community, the Environment, and a Sustainable Future. Beacon Press, Boston.

Dugin, Alexander (2017): A negyedik politikai eszme. Kvintesszencia Kiadó, Debrecen.

The Economist (2011): Quantifying History. Two Thousand Years in One Chart. The Economist, June 28, www.economist.com/graphic-detail/2011/06/28/two-thousand-years-in-one-chart.

Fehér M. István (szerk.) (1991): Utak és tévutak. Elôadások Heideggerrốl. Atlantisz Kiadó, Budapest.

Felkai Gábor (1993): Jürgen Habermas. Áron Kiadó, Budapest.

Habermas, Jürgen (1954): Die Dialektik der Rationalisierung. Merkur, Jg. 8, Heft 78, 701-724.

Harford, Tim (2008): Krugman Wins Nobel Prize for Economics. Financial Times, October 13, www.ft.com/ content/c9cc37ee-991b-11dd-9d48-000077b07658.

Hésziodosz (1974): Istenek születése. Munkák és napok. Magyar Helikon, Budapest.

Homonnay Farkas (1946): Banktörténet. A fizetésközvetités fejlődése Babylontól napjainkig. Officina Kiadó, Budapest. József Attila (1980): Munkások. In: József Attila minden verse és versforditása. Szépirodalmi Könyvkiadó, Budapest. 
Kierkegaard, Søren (1997): Filozófiai morzsák. Göncöl Kiadó, Budapest.

Kotler, Philip (1998): Marketingmenedzsment. Múszaki Könyvkiadó, Budapest.

Krugman, Paul R. - Obstfeld, Maurice (2003): Nemzetközi gazdaságtan. Elmélet és gazdaságpolitika. Panem Könyvkiadó Kft., Budapest.

Krugman, Paul R. (2012): Elég legyen a válságból! Most! Akadémiai Kiadó, Budapest.

Marcuse, Herbert (1990): Az egydimenziós ember. Kossuth Könyvkiadó, Budapest.

Marx, Karl (1973): A tôke I. Kossuth Könyvkiadó, Budapest.

Meyer Dietmar (1995): Az új növekedéselmélet. Közgazdasági Szemle, 42. évf., 4. sz., 387-398.

Mill, John S. (1900): Principles of Political Economy II. The Coloniel Press, London, New York.

Petôné Csuka Ildikó - Majoros András - Somogyi Ferenc (2008): A „homo oeconomicus” fogságában. Polgári Szemle, 4. évf., 2. sz.

Polányi Károly (1984): Kereskedelem, piacok és pénz az ókori Görögországban. Gondolat Kiadó, Budapest.

Portfolio.hu (2014): Elképesztô számok a világ adósságáról. Portfolio.hu, március 10., www.portfolio.hu/ gazdasag/elkepeszto_szamok_a_vilag_adossagarol.196333.html.

Rawls, John (1997): Az igazságosság elmélete. Osiris Kiadó, Budapest.

Semlyén István (szerk.) (1982): Népesedésrobbanás - egyke. Kriterion Könyvkiadó, Bukarest.

Smith, Adam (2011): Vizsgálódás a nemzetek jólétének természetérôl és okairól II. Napvilág Kiadó, Budapest.

Somogyi Ferenc (2015): Tigrislovaglás, avagy a globalitás áfuma ellen való orvosság. Kairosz Kiadó, Budapest. Tillman József Attila (szerk.) (2004): A késốujkor józansága II. Göncöl Kiadó, Budapest. 